\title{
Applications of Thermal Imaging in Agriculture-A Review
}

\author{
Roselyne Ishimwe ${ }^{1 *}$ K. Abutaleb1, F. Ahmed ${ }^{2}$ \\ ${ }^{1}$ Department of Geography, Environmental Management and Energy Studies, University of Johannesburg, \\ Johannesburg, South Africa \\ ${ }^{2}$ School of Geography, Archaeology and Environmental Studies, University of Witwatersrand, Johannesburg, \\ South Africa \\ Email: *ishiroste@gmail.com, khaledat@uj.ac.za, fethi.ahmed@wits.ac.za
}

Received 2 July 2014; revised 2 August 2014; accepted 1 September 2014

Copyright (C) 2014 by authors and Scientific Research Publishing Inc.

This work is licensed under the Creative Commons Attribution International License (CC BY). http://creativecommons.org/licenses/by/4.0/

(c) (7) Open Access

\begin{abstract}
In thermal remote sensing the invisible radiation patterns of objects are converted into visible images and these images are called thermograms or thermal images. Thermal images can be acquired using portable, hand-held or thermal sensors that are coupled with optical systems mounted on an airplane or satellite. This technology is a non-invasive, non-contact and non-destructive technique used to determine thermal properties and features of any object of interest and therefore it can be used in many fields, where heat is generated or lost in space and time. Potential use of thermal remote sensing in agriculture includes nursery and greenhouse monitoring, irrigation scheduling, plants disease detection, estimating fruit yield, evaluating maturity of fruits and bruise detection in fruits and vegetables. This paper reviews the application of thermal imaging in agriculture and its potential use in various agricultural practices.
\end{abstract}

\section{Keywords}

Infrared Radiation, Infrared Thermography, Thermal Imaging, Crop, Agriculture

\section{Introduction}

Thermal remote sensing is the branch of remote sensing that deals with the acquisition, processing and interpretation of data acquired primarily in the thermal infrared (TIR) region of the electromagnetic (EM) spectrum [1]. Thermal remote sensing differs from optical remote sensing by measuring emitted radiations from the surface of the target object, whereas optical remote sensing measures reflected radiations of the target object under consideration [2].

"Corresponding author. 
Thermal wavelength region in terrestrial remote sensing ranges from 3 to $35 \mu \mathrm{m}$ but interpretation of the data in 3 - $5 \mu \mathrm{m}$ is complicated due to overlap with solar reflection in day imagery and 17 - $25 \mu \mathrm{m}$ regions are still not well investigated. As a consequence 8 - $14 \mu \mathrm{m}$ regions have been of greatest interest for thermal remote sensing [1] since this is where the atmosphere is fairly transparent and the signal is only lightly attenuated by atmospheric absorption [3].

Thermal remote sensing exploits the fact that everything above absolute zero $\left(0 \mathrm{~K}\right.$ or $-273.15^{\circ} \mathrm{C}$ or $\left.-459^{\circ} \mathrm{F}\right)$ emits radiation in the infrared range of the electromagnetic spectrum [1] hence approximately $80 \%$ of the energy thermal sensors received in the thermal wavelength region is emitted by land surface, making surface temperature as the easiest variable to extract from the thermal infrared signal [4]. Thermal infrared has grown into an important technology that is applied directly by users on the ground using infrared instruments that are portable and even hand-held or by using thermal sensors coupled with optical systems [5]. Therefore, thermal imaging data may be used directly or indirectly for many applications such as civil engineering, industrial maintenance, aerospace, medicine, pharmacy and veterinary. The application of thermal imaging is gaining popularity in agriculture in recent years [6] due to the reductions in cost of the equipment and simple operational procedure that have created opportunities for its application in several fields of agricultural and food industries [7] and it is presently refined for integration into precision farming [8].

Thermal properties of plant leaves are affected by a complex heterogeneous internal structure that contains a certain amount of water per unit area. For that reason, it is possible to have research on individual plant with thermal remote sensing because of the versatility, accuracy and high resolution of the infrared thermography [9]. Nevertheless, accurate thermal measurements depend on environmental conditions, which influence the thermal properties of the visualized crop. Therefore, calibration of images according to weather conditions is necessary for comparison between image data obtained during different measuring periods and growth seasons [10]. Thermal remote sensing technology can be used in all agricultural materials and processes, where heat is generated or lost in space and time [11]. Potential use of thermography in agriculture includes nursery monitoring, irrigation scheduling, soil salinity detection, disease and pathogen detection, yield estimation, maturity evaluation and bruise detection.

The purpose of this paper is to review the different thermal sensors that can be used in agriculture as well as summarize various studies conducted on the potential application of thermal imaging in agriculture.

\section{Thermal Sensors}

An infrared thermal imaging system comprises of a thermal camera equipped with infrared detectors, a signal processing unit and an image acquisition system. Thermal imaging systems are evaluated on their thermal sensitivity, scan speed, image resolution, and intensity resolution [6]. Table 1 describes the specifications and primary purpose of operational thermal sensors (still operating) that can be used in various studies that will be discussed in this paper.

\subsection{Spectral Reflectance Properties of Vegetation Parameters}

The traditional methods of measuring vegetation parameters are reliable; however they are labor intensive, time consuming and only practical for areas of limited size [12] [13]. More recently remote sensing provides more accurate data for vegetation parameters characterization than traditional techniques because it provides continuous spatial coverage over a large area at repetitive intervals. Vegetation spectral reflectance characteristics depend on leaves properties (leaf canopy orientation and structure) but the amount of energy reflected for a particular wavelength depends on leaf pigmentation, thickness, cells composition(cells structure), and on the amount of water in the leaf tissue [14].

Green plant leaves typically display very low reflectance and transmittance in visible regions of the spectrum ( 0.4 to $0.7 \mu \mathrm{m})$ due to strong absorbance by photosynthetic and accessory plant pigments since controlling factors for this region are leaves pigments (Chlorophyll and anthocyanins) [15] [16]. By contracts in near infrared region $(0.7-1.1 \mu \mathrm{m})$ reflectance increases strongly since there is considerable scattering at mesophyll cell wall interfaces and there is minimal absorbance by pigments, the controlling factor of this part is leaf structure. This sharp difference of vegetation spectral reflectance properties between the visible and near infrared wavelengths helps the majority of remote sensing approaches for monitoring and managing crop vegetation [17].

Spectral properties of plant in the middle or shortwave-infrared (SWIR: $1.1-2.5 \mu \mathrm{m}$ ) are strongly controlled 
Table 1. Thermal infrared sensors.

\begin{tabular}{|c|c|c|c|c|}
\hline $\begin{array}{l}\text { Name of } \\
\text { the sensor }\end{array}$ & $\begin{array}{l}\text { Wavelength } \\
\qquad(\mu \mathrm{m})\end{array}$ & Waveband & $\begin{array}{c}\text { Spatial } \\
\text { resolution (m) }\end{array}$ & Primary purpose \\
\hline \multirow{2}{*}{ AATSR/ENVISAT } & 10.8 & Band 6 & 1000 & Sea surface temperature \\
\hline & 12 & Band 7 & 1000 & Sea surface temperature \\
\hline \multirow{7}{*}{ ABI/GOES-R } & 7.34 & Band 10 & 2000 & Lower-level water vapor, winds and $\mathrm{SO}_{2}$ \\
\hline & 8.5 & Band 11 & 2000 & Total water for stability, cloud phase, dust, $\mathrm{SO}_{2}$, rainfall \\
\hline & 9.61 & Band 12 & 2000 & Total ozone, turbulence, winds \\
\hline & 10.35 & Band 13 & 2000 & Surface and cloud \\
\hline & 11.2 & Band 14 & 2000 & Imagery, SST, clouds, rainfall \\
\hline & 12.3 & Band 15 & 2000 & Total water, ash, SST \\
\hline & 13.3 & Band 16 & 2000 & Air temperature, cloud heights and amounts \\
\hline \multirow{5}{*}{ Aster } & $8.12-8.47$ & Band10 & 90 & Surface temperature \\
\hline & $8.47-8.82$ & Band11 & 90 & Surface temperature \\
\hline & $8.92-9.27$ & Band12 & 90 & Surface temperature \\
\hline & $10.25-10.95$ & Band13 & 90 & Surface temperature \\
\hline & $10.95-11.65$ & Band14 & 90 & Surface temperature \\
\hline \multirow{3}{*}{ AVHRR } & $3.50-3.93$ & Band3 & $\begin{array}{l}4400 \text { and } 1100 \\
\text { in USA }\end{array}$ & Night cloud mapping, sea surface temperature \\
\hline & $10.30-11.31$ & Band4 & $\begin{array}{l}4401 \text { and } 1100 \\
\text { in USA }\end{array}$ & Night cloud mapping, sea surface temperature \\
\hline & $11.50-12.50$ & Band5 & $\begin{array}{l}4401 \text { and } 1100 \\
\text { in USA }\end{array}$ & Sea surface temperature \\
\hline \multirow[b]{2}{*}{$\begin{array}{l}\text { Daedalus (AMS) } \\
\text { AA3600DS }\end{array}$} & $3.0-5.4$ & Band 9 & 5 & Oil spill detection, mapping and detection of fire and geologic areas \\
\hline & $8.5-12.5$ & Band 10 & 5 & $\begin{array}{l}\text { Geologic, water suspended sediment, } \mathrm{H}_{2} \mathrm{O} \text { temp-Spring } \\
\text { and seep detection, water algae, forest inventory, crop vigor studies, } \\
\text { fire detection and oil spill detection mapping }\end{array}$ \\
\hline \multirow[b]{2}{*}{$\begin{array}{l}\text { Daedalus (AMS) } \\
\text { AA3607DS }\end{array}$} & $3.0-5.4$ & Band 15 & 2.5 & Oil spill detection/mapping, fire detection/mapping, geologic mapping \\
\hline & $8.5-12.5$ & Band 16 & 2.5 & $\begin{array}{l}\text { Geologic, water suspended sediment, } \mathrm{H}_{2} \mathrm{O} \text { temp-Spring and } \\
\text { seep detection, water algae, forest inventory, crop vigor studies, } \\
\text { fire detection and oil spill detection mapping }\end{array}$ \\
\hline \multirow{2}{*}{ Daedalus (ATM) } & $\begin{array}{l}8.5-14.0 \\
\text { High gain }\end{array}$ & Band 11 & 25 & $\begin{array}{c}\text { Earth resources mapping, vegetation/land cover mapping, } \\
\text { and geologic studies }\end{array}$ \\
\hline & $\begin{array}{l}8.5-14.0 \\
\text { Low gain }\end{array}$ & Band 12 & 25 & $\begin{array}{c}\text { Earth resources mapping, vegetation/land cover mapping, } \\
\text { and geologic studies }\end{array}$ \\
\hline $\begin{array}{c}\text { DAIS } 7915 \\
\text { (Airbone Sensor) }\end{array}$ & $8.0-12.6$ & Band 6 & 20 & Surface temperature \\
\hline IRMSS/CBRES & $10.4-12.5$ & Band 09 & 80 & $\begin{array}{c}\text { To assist in thermal mapping, soil moisture and vegetation studies, } \\
\text { separates land and water sharply. }\end{array}$ \\
\hline IRS/HJ-1 & $10.5-12.5$ & Band 4 & 300 & land surface temperature \\
\hline \multirow{2}{*}{ Landsat 8} & $10.30-11.30$ & Band 10 & 100 & Thermal mapping and estimated soil moisture \\
\hline & $11.50-12.50$ & Band 11 & 100 & Improved thermal mapping and estimated soil moisture \\
\hline Landsat 7 ETM+ & $10.40-12.50$ & Band 6 & 60 & Thermal mapping and estimated soil moisture \\
\hline MERSI/FY-3 & 11.25 & Band 5 & 250 & Land, cloud and aerosols properties \\
\hline
\end{tabular}




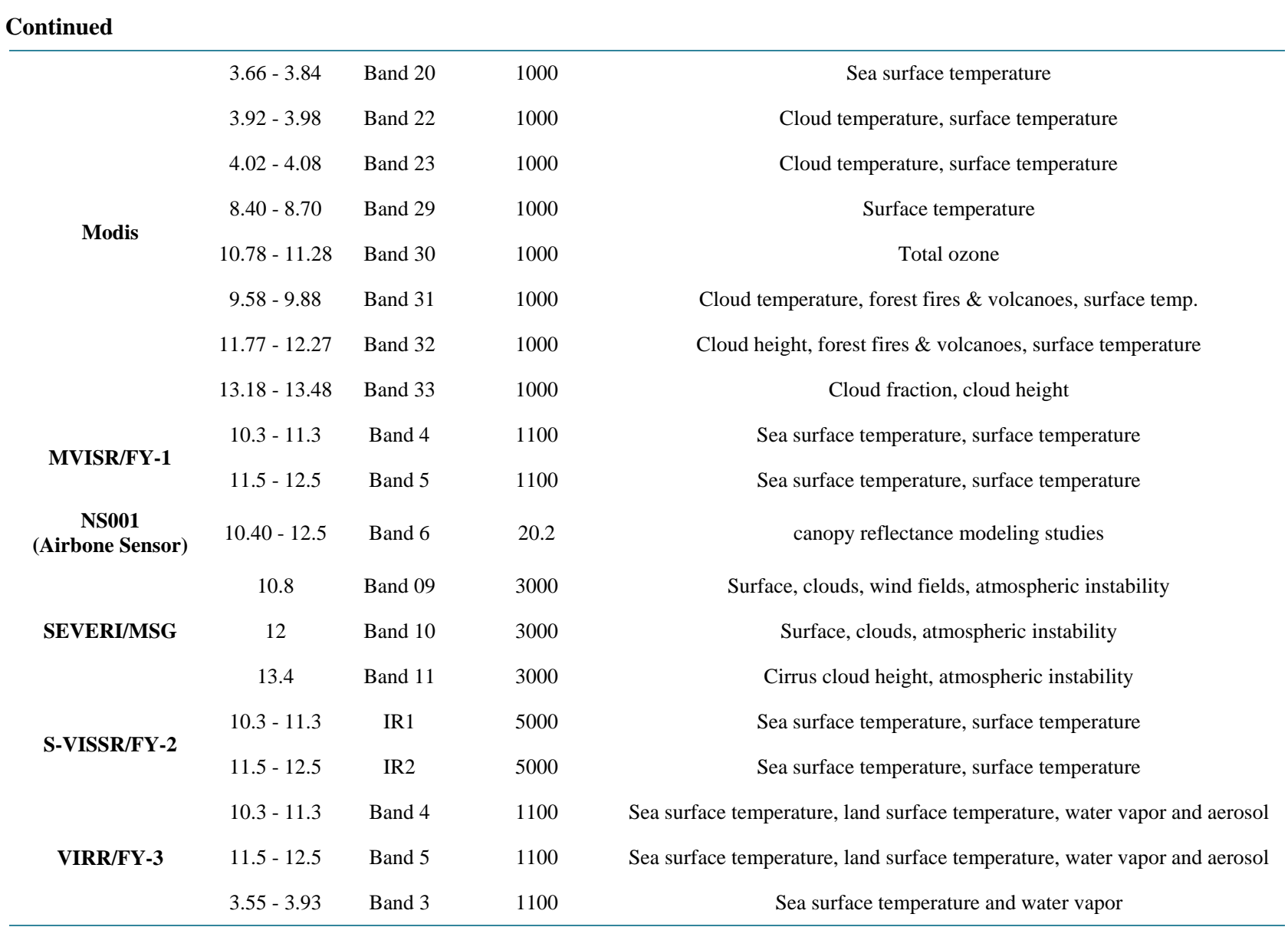

by water content in the plant tissue therefore reflectance in this region is relatively high for vigorously growing vegetation but decreases as tissues dehydrate [16]. Many remote sensing studies ([18]-[23]) have made use of the visible to short-wave infrared (VIS-SWIR; $0.4-2.5 \mu \mathrm{m}$ ) spectral properties of plants, to study the spatial and temporal variations in vegetation patterns, however data from the VIS, NIR and SWIR are not sufficient to explain the structure and chemical characteristics of vegetation [13] as fundamental absorption features related to various compounds and leaf structure of a crop vegetation occur in thermal infrared domains (TIR: 6.0 - 14.0 $\mu \mathrm{m})$ [24]-[26]. Despite primary absorption features, strong and wide atmospheric windows in the MIR and TIR, little is known about the optical properties of the vegetation in these spectral domains [26] due to a number of challenges such as lack of equipment and laboratories that enable measurements of the TIR reflectance or emissivity of plants (i.e. TIR spectroradiometers), low signal to noise ratios (SNR), and the subtle and complex nature of the spectral features of vegetation [13], However some authors, in their work on other aspects, have brought to light the potential of TIR measurement for characterizing vegetation parameters where they recognize that organic compounds and absorption features of plant leaves in TIR are related to the fundamental molecular vibrations of various compounds present in plant leaves [24]. Thus the principal cause of spectral features in TIR region is leaf epidermal materials (i.e. cell wall and cuticular membrane) [27]-[29] and [24] and leaf water content [25] and [26].

\subsection{Nursery Monitoring}

A nursery is a place where plants are propagated and grown to usable size; plants can be grown in open fields, on container fields and in tunnels or greenhouses. Early detection of seed quality and seed monitoring would benefit from a tool that identifies individual viable and nonviable seeds before use [30] and it facilitates to correct changes on cultural practices before stress is well established [31]. Periodic inventories, visual inspection and conventional seed viability testing methods are commonly used to monitor seeds viability but all of those 
method are destructive, time-consuming, and labor-intensive [32].

Presently researchers and nursery managers have become more aware that physiological attributes of seeds are not identifiable visually [33] hence thermal infrared imaging techniques were proposed as a possible alternative to traditional methods of seed viability evaluation.

Thermal profile of seeds can be used to detect subtle changes in temperature, these changes vary with viability [30], and this enables the classification and separation of viable seeds from non-viable ones [34]. According to [11] and [35] significant positive correlations were found between seedling temperature and degree of damage where the coolest seedling had higher survival rate than the warmest seedling therefore thermal signal decay characteristics can depend on the seed aging conditions or seed viability, which are significantly associated with changes in the seed membrane permeability [32] thus IR thermography can be applied to detect seed and seedlings viability, physical damage, physiological disorders and evaluation of the growth process of seeds, seedlings and plants inside the nurseries and greenhouses

\subsection{Irrigation Scheduling}

Irrigation is essential for agriculture production as in-season rainfall is inadequate to meet crop water demand for this reason poor irrigation timing and insufficient applications of water are ubiquitous factors limiting production in many agricultural regions [16]. Various studies have shown that the thermal infrared (TIR) part of the spectrum is more sensitive to determine water stress than other reflectance in visible, NIR, or SWIR wavelengths since infrared (IR) thermometer measures the thermal temperature of the plant leaves or a crop canopy and it is known that once plants go into water stress; their stomata begin to close and cease to transpire, causing the plant to "heat up" and the canopy temperature to rise [36]. In addition thermal imaging appears to have potential advantages over gas-exchange measurement when screening for stomatal responses in phenotyping plant studies [37]. As a consequence considerable researchers have been focusing on the use of thermal imaging or IR thermometers to schedule irrigation.

A wide range of researchers that use IR thermometer imagery to schedule irrigation focuses on plant parameters such as: plant temperature and evapotranspiration rate: ([38]-[48]) as well as stomatal conductance, and closing of stomata ([37] [49]-[51]). Monitoring stomatal conductance can be a better indicator of plant response to drying soil than monitoring water potential because reductions in stomatal conductance can occur even before any change in plant water status [52].

Methods for using TIR to assess spatial variation in soil water availability also have utility in precision agriculture applications [16]. As an example [53] showed that plant growth and soil water deficit vary spatially and temporally in a crop field where increased soil water deficit within the root zone of plants increases canopy temperature which leads to an increase in stomatal conductance, and suggest that this could be used as an estimator to schedule irrigation.

Newly researches combine thermal remote sensing with other methods to access crop water stress and irrigation scheduling. [54] developed an algorithm that can assess automatically canopy temperature by aligning an optical image taken from the plant canopy with the IR image, from simple color identification techniques in combination with Gaussian mixture distribution extraction techniques and based on measurement of data acquired from an IR thermography they were able to extract successfully and automatically the canopy temperature distribution of the leaf. A new approach was developed by [55] to schedule irrigation based on ground remote sensing systems. Infrared radiometers and a conventional meteorological system were stationed on top of a linear move irrigation system. The output signals were collected remotely in a personal computer (PC) that was equipped with specific code to solve the Penmane-Monteith (PM) equation for parameterization of aerodynamic and canopy resistances which were then used to calculate the water requirement of the plants. From Infrared radiometric system they were able to control remotely all components that are required to improve irrigation management, including the automatic data collection, models, hardware and software, in addition their remote sensing approach does not require signals from the soil (as usually practiced) but instead it is based on signals that are emitted directly from plants. [56] combines hyperspectral and thermal imageries collected from airborne sensors on a farm-level field experiments of maize and sorghum with different water irrigation treatments imposed. Based on the results obtained in their study, Author's states that the integrated use of hyperspectral indices, fluorescence and thermal imageries can guarantee good results for irrigation scheduling and crop water stress identification. 


\subsection{Soil Salinity Detection}

Soil salinity causes severe environmental degradation that impedes crop growth and overall regional production [57] Soil salinity information can be extracted from thermal imageries as emitted radiance can provide subsoil information that reflected radiation cannot [58].

[59] studied the application of thermography to rapidly diagnosing salinity stress with a high degree of temperature resolution in potted ornamental crops Syngonium podophyllum and Philodendron erubescens that were transplanted to pots in a greenhouse in Almeria (Spain). Salinity treatments were 1, 2, 6 or $12 \mathrm{dS} \cdot \mathrm{m}^{-1}$ of electric conductivity in a nutrient solution. Thermography coupled with adequate software clearly shows the effect of salinity on the potted plants, and this effect was maintained for over 30 days thus the author states that thermography can be an early useful method to diagnose saline stress in potted plants.

Therefore thermal Infrared (TIR) radiation is important for salinity studies, although only few studies have used this technology to study and diagnose soil salinity stress on crops.

\subsection{Disease and Pathogen Detection}

During plant-pathogen infection, the physiological state of the infected tissue is altered, such as changes in photosynthesis, transpiration, stomatal conductance, accumulation of Salicylic acid (SA) and even cell death [60]. Foliar disease can directly be detected by modern optical sensor technology. Using hyperspectral reflectance images [61] and [62] were able to identify powdery mildew of barley, diseased cucumber leaves and yellow rust of wheat respectively. But digital infrared thermography have the potential to identify and quantify with high spatial resolution management zones in disease control and associated pathogens, as they are sensitive to physiological disorders associated with fungal attack as well as disease [63], in addition leaf diseases often affect plant transpiration.

Thermal infrared has been proved by various researchers to be a useful tool for the pre-symptomatic effect of disease and pathogen on plant. [63]-[65] used thermal infrared to detect Pseudoperonospora cubensis that causes downy mildew in cucumber, The maximum temperature difference (MTD) within a leaf or a canopy turned out to be suitable for the differentiation of infected and non-infected tissue under controlled conditions, transpiration rate and leaf temperature were similar for healthy and infected leaves under non controlled conditions but for infected tissues, transpiration rates showed higher variation depending on disease symptoms. However, [60] found a decrease in leaf temperature of about $0.5^{\circ} \mathrm{C}-1.3^{\circ} \mathrm{C}$ lower for the infected leaves than the healthy leaves while they were assessing the different temperature distribution between the leaves infected by tobacco mosaic virus strain-TMV-U1 and the non-infected leaves within different tomato species using digital infrared thermal imaging in combination with microscopic observations.

Later on [66] explain this decrease and increase of infected leaves temperature while they were assessing scab disease on apple leaves using infrared thermography and they found that MTD increased with scab development and was strongly correlated to the size of infection sites. However in the later stages of the disease, the MTD decreased because of leaf senescence and leaf transpiration was increased by all stages of scab development, therefore, MTD may be used not only for the differentiation between diseased and non-diseased leaves, but also for disease quantification.

TIR could also be used to detect pathogen before visible symptoms occur; [67] explored the potential of thermal imaging for pathogen detection (Plasmopara viticola) in grapevine (Vitis vinifera L. cv. Riesling) on well irrigated or non-irrigated grapevines. Experiments were conducted under greenhouse conditions to monitor leaf temperature of Plasmopara viticola pathogen-infected and non-infected areas. Four different treatments were used: (1) irrigated to field capacity and non-inoculated vines; (2) irrigated to field capacity and inoculated vines; (3) non-irrigated and non-inoculated vines; and (4) non-irrigated and inoculated vines. The analysis of thermal images showed that pathogen development caused an increase in leaf temperature at the point of infection in irrigated vines, non-irrigated vines showed a lower temperature at the sites of inoculation.

Thermal imaging is a straightforward choice for providing information for pre-symptomatic diagnosis of biotic stresses before the appearance of visible necrosis on leaves by visualizing and analyzing the temperature difference between infected and non-infected leaves.

\subsection{Yield Estimation and Forecasting}

Crop yield estimation is very important because such predictions warn the decision makers about potential re- 
duction in crop yields, Time series data models are the commonly used methods to estimate yield for many crops in almost all parts of the world. But most of the time, high deviation is observed in the actual yield from the forecasted yield [7]. Thermal imaging can be used to estimate yield as thermography is based on sensing an object's own heat radiation. However, only a few reports can be found on the application of thermal imaging in estimating and forecasting yield

[68] analyzed the relationship between wheat yield and daytime measurement of temperature difference between foliage and ambient air temperature. For foliage temperature measurement, they used a thermal camera that received the infrared radiation in 8 - $14 \mu \mathrm{m}$ spectral wavelengths. Micrometeorological data were also collected during the wheat growing stages. The experiment was conducted for two crop seasons (1982 and 1983) on a red-brown soil in Australia. Transpiration and canopy stomatal resistances to water vapor transport were predicted from the collected data, the predicted transpiration and $\mathrm{CO}_{2}$ assimilation rates were found to be closely related to yield within each year but not between years. As a result it was stated that infrared thermometry would be a useful technique for studying yield variations in agronomic experiments where these variations are due to stomatal control.

After almost two decades [69] developed fruit detection algorithm with thermal imaging to estimate the number of apple fruits on the basis of temperature gradients between fruits and their background. At the same time, on each imaged tree, all fruits were manually counted and diameters of the fruits were measured with sliding calipers. The results of the study showed that a close correlation $\left(R^{2}=0.83-0.88\right)$ existed between manually counted fruits and fruits determined by thermal imaging. The correlation coefficient was $\mathrm{R}^{2}=0.68$ to 0.70 between manually measured diameter and the diameter of fruit determined by imaging.

[70] conducted a study that focused on fruit recognition from the canopy using thermal imaging, to enhance the robotic harvesting of fruit, which is an alternate for harvesting by hand. Thermal images were acquired on 24 $\mathrm{h}$ cycles at $15 \mathrm{~min}$ interval using a thermal infrared camera, after analyzing images with Matlab they found that from evening 16:00 until early morning, fruit temperature was higher than the leaf by about $1.6^{\circ} \mathrm{C}$ while in the other time range, it was higher only at less than $0.6^{\circ} \mathrm{C}$. The authors suggested that thermal imaging has a potential to distinguish between fruit and canopy from afternoon until midnight.

[71] utilizes thermal infrared image for inversion of winter wheat yield and biomass with different technology of irrigation (drip irrigation, sprinkler irrigation, flood irrigation), the authors considered the fact that the amount of yield of a crop is more related to the amount of water received during the growing period. Their research was subdivided into tree stages as follows, Firstly, the infrared crop water stress index (ICWSI) was obtained by using thermal infrared camera, Secondly the infrared index data was checked for correctness and finally model was developed using ICWSI to predict soil moisture, biomass and yield of wheat. Various crop prediction models were used but cubic model proved to be the best to predict yield based on thermal imaging, therefore the authors indicated that thermal infrared images can be used potentially for inversion of winter wheat yield.

Recently, [72] conforms the superiority of thermography technology for predicting winter wheat yield. The authors applied BP neural network in predicting winter wheat yield based on thermography. Using thermal camera to obtain canopy temperature for winter wheat, ICWSI was then calculated in the main water requirement stage. The performance of a BP neural network was tested with ICWSI values for three different periods in one irrigation circles as independent input factor and observed winter wheat yield after harvest as the output. The result showed a the maximum relative error of $3.42 \%$, therefore the authors states that BP neural network in combination with ICWSI using thermal images successfully and accurately predict the yield of winter wheat.

Since the accuracy of yield forecasting by thermometry is very promising, this technique may be used as a complementary method to other methods [7]. However, no further research is reported about yield estimation for other crops (e.g., Maize, Soybean, etc.) using thermal imaging which requires continuous detection and counting [73].

\subsection{Maturity Evaluation}

Crop maturity assessment is commonly achieved by crop dissection and visual inspection [74] even though several automatic methods are available. These approaches are both labor intensive and subjective due to the repeatability of measurement and limiting number of observation made by a single observer [75]. It is known that transpiration resistance grows as well as the plant physiological age increases until the plant reaches the maximum value, in many kinds of plant, this maximum value coincides with the stage of maturity or ripeness [76] 
and transpiration resistance diminish as plant ageing begins whence infrared thermography can be used to assess crop maturity.

[77] assessed the maturity of Tomato, Japanese pear, and Japanese persimmon (one vegetable and two fruits respectively) using infrared thermometry. These were divided into three grades of maturity that are immature, mature, and over-ripe based on color, firmness, and sugar content. Samples were kept in constant room temperature for more than $24 \mathrm{~h}$ before measurements. The temperature differences ranged between $0.5^{\circ} \mathrm{C}$ to $1.0^{\circ} \mathrm{C}$ for fruit and vegetables in three grades of maturity, whereas, the surface temperature of immature fruits stored at higher temperature was slightly lower than that of mature and over-ripe fruits.

[78] suggested after conducting a study on the use of thermography for determination of mechanical damage, bruising, and maturing of apples (Jonagold, Cox), that maturity of fruits and vegetables can be estimated by thermal imaging, even different varieties could be identified if they are of the same ripeness. Therefore thermal imaging systems are suitable for examining maturity and quality of produce as detailed thermal analyses of the transpiration behavior of the produce and its interrelation with the environment allow the determination of the optimal harvest date and the adapted design of postharvest machinery [76]. Nevertheless there is a need for more research on the use of thermal imaging for maturity detection of other crops.

\subsection{Bruise Detection}

Bruises and scratches are the most common forms of damage on the surface of fruits and vegetables during transportation and handling [7]. Bruising is defined as damage of fruit tissue as a result of external forces which cause physical changes of texture or chemical changes of color, smell and taste [79]. With the development in imaging technology on-line detection of bruises on fruits \& vegetables is feasible. Non-destructive methods for detecting bruise damage in fruits have been reported using imaging technologies including the Multispectral and Hyperspectral NIR-based technique ([80]-[86]). Thermal imaging offers a potential alternative technique for bruise detection, unlike NIR based techniques it does not require an illumination source for spectral reflectance like which can be affected by the varied skin color of apples or by the illumination setup [87]. The inner defects of fruit tissue which leads to local changes of thermal properties are responsible for obtaining thermal contrasts between bruised and sound areas on the fruit surface.

The first study of detecting bruise using thermal imaging was done by [88], their study determined the effect of surface defects on temperature distribution for apple, Satsuma mandarin, and natsudaidai fruits. Artificial bruises were made on the fruits by pressing and scratching. Thermal images were taken with a thermal camera (wavelength $8-14 \mu \mathrm{m}$ ). The temperature difference between bruised and sound skin was found to be usually in the range of $0.2^{\circ} \mathrm{C}$ to $1.0^{\circ} \mathrm{C}$, with measuring times of at least $10 \mathrm{~min}$ and the temperature at the bruises was lower than that of unbruised skin.

[89] used thermal imaging method to detect bruises in tomato where artificially bruised tomatoes were heated in microwave oven for 14 second and then thermally imaged and after all treatment, measurement of temperature difference between the intact and bruised parts was in the range of $0.5^{\circ} \mathrm{C}$ to $1.0^{\circ} \mathrm{C}$. [87] determined the capability of the thermal imaging method that applies forced convection to detect bruises in three apple varieties (Fuji, Red delicious, and Macintosh), Apples were thermally imaged for $3 \mathrm{~min}$. It was determined that before treatment thermal imaging could not detect the bruises in apple. But after treatment the bruised tissue showed at least $1^{\circ} \mathrm{C}$ to $2^{\circ} \mathrm{C}$ cooler than sound tissue within 30 to 180 second thus the author's state that the temperature differences were due to thermal diffusivity instead of thermal emissivity

[90] developed a method to detect early bruising in apple varieties, Jonagold, Champion and Gloster using pulsed-phase thermography (PPT). Samples were subjected to bruising by a specific procedure and stored at room temperature for $1 \mathrm{~h}$ before thermographic bruise assessment. In the first stage of the study (no heat stimulation), the temperature difference between sound and bruised areas as well as between shallow and deeper bruises were close to $0^{\circ} \mathrm{C}$, while, after heating apples for $1 \mathrm{~s}$, the temperature of the bruised part was colder and varies between $0.9^{\circ} \mathrm{C}$ and $1.5^{\circ} \mathrm{C}$ for Jonagold, 0.9 and $1.8^{\circ} \mathrm{C}$ for Champion, and $1.0^{\circ} \mathrm{C}$ and $2.1^{\circ} \mathrm{C}$ for Gloster apples.

In spite of the fact that infrared thermography techniques have many qualities in bruise detection, such as nondestructive, non-contact, and allow for full-field imaging and fast inspection speed, it has also some limitations caused by the measurement sensitivity. However, this limitation can be overcome by combining infrared thermography with other technologies such as lock-in techniques, whereby it combine several technologies and control systems that are supported by computerized image processing techniques. Thus, lock-in technique has 
been applied to infrared thermography to enhance its detection sensitivity [91]. [92] uses infrared lock in thermography to evaluate bruises on pears fruits. They measured the thermal emission signals from pears using a highly sensitive mid-infrared thermal camera, by applying the lock-in method to infrared thermography, the detection sensitivity and signal to noise ratio were enhanced because of the phase-sensitive narrow-band filtering effect. Thermal characteristic response of pears was analyzed on the basis of phase images. Author's found that a greater phase difference corresponds to greater damage of the pear specimens, because the damaged area causes thermal wave delay, therefore their states that the lock-in thermography technique can be used for the detection of damage on pear samples.

\section{Conclusion}

Thermal imaging has been growing fast and playing an important role in various fields of agriculture starting from nursery monitoring, irrigation scheduling, soil salinity stress detection, plants disease detection, yield estimation, maturity evaluation and bruise detection of fruits and vegetables. This technique gains the popularity in agriculture due to its higher temporal and spatial resolutions images. However, intensive researches need to be conducted for its potential application in other various processes of agriculture (e.g. Yield forecasting) that are not yet investigated. In spite of the fact that it could be used in many agriculture operations during pre-harvest and post-harvest period, as a noncontact, non-destructive technique, it has some drawbacks unlike with other remote sensing imaging because high resolution thermal imaging are costly and accurate thermal measurements depend on environmental and weather conditions thus it may not be possible to develop a universal methodology for its application in agricultural operations since thermal behaviors of crops vary with climatic conditions.

\section{Acknowledgments}

We thank University of Johannesburg and University of Witwatersrand for providing financial assistance.

\section{References}

[1] Prakash, A. (2000) Thermal Remote Sensing: Concepts, Issues and Applications. International Archives of Photogrammetry and Remote Sensing, 33, 239-243.

[2] Sabins Jr., F.F. (1996) Remote Sensing: Principles and Interpretation. 3rd Edition, W.H. Freeman, New York.

[3] Mallick, J. (2006) Satellite Based Analysis of the Role of Land Use/Land Cover and Vegetation Density on Surface Temperature Regime of Delhi, India. Master's Thesis, University of Twente, The Netherlands.

[4] Dale, Q.A. and Luvall, C.J. (2004) Thermal Remote Sensing in Land Surface Processing. CRC Press, Boca Raton.

[5] Short, N.M. (2005) Federation of American Scientist. Federation of American Scientist. http://fas.org/irp/imint/docs/rst/Sect9/Sect9_1.html

[6] Vadivambal, R. and Jayas, D.S. (2011) Applications of Thermal Imaging in Agriculture and Food Industry - A Review. Food Bioprocess Technology, 4, 186-199. http://dx.doi.org/10.1007/s11947-010-0333-5

[7] Manickavasagan, A., Jayas, D., White, N., and Paliwal, J. (2005) Applications of Thermal Imaging in Agriculture-A Review. The Canadian Society for Engineering in Agriculture, Food, and Biological Systems, 05-002.

[8] Liu, Q., Gu, X., Li, X., Jacob, F., Hanocq, J., Friedl, M., et al. (2000) Study on Thermal Infrared Emission Directionality over Crop Canopies with TIR Camera Imagery. Science in China Series E: Technological Sciences, 43, 95-103. http://dx.doi.org/10.1007/BF02916583

[9] Hu, Z., Du, W. and He, X. (2011) Application of Infrared Thermography Technology for Irrigation Scheduling of Winter Wheat. 2011 International Conference on Multimedia Technology (ICMT), 26-28 July 2011, Hangzhou, 494-496.

[10] Nilsson, H. (1995) Remote Sensing and Image Analysis in Plant Pathology. Annual Review of Phytopathology, 33, 489-527. http://dx.doi.org/10.1146/annurev.py.33.090195.002421

[11] Hellebrand, H., Beuche, H. and Linke, M. (2002) Thermal Imaging: A Promising High-Tec Method in Agriculture and Horticulture. In: Blahovec, J. and Kutilek, M., Eds., Physical Methods in Agriculture: Approach to Precision and Quality, Kluwer Academic/Plenum Publishers, New York, 411-427.

[12] Pu, R., Gong, P. and Biging, G.S. (2003) Simple Calibration of AVIRIS Data and LAI Mapping of Forest Plantation in Southern Argentina. International Journal of Remote Sensing, 24, 4699-4714. http://dx.doi.org/10.1080/0143116031000082433

[13] Ullah, S. (2013) Thermal Plant. Characterizing Vegetation Parameters Using Mid to Thermal Infrared Hyperspectral Remote Sensing. PhD Thesis, University of Twente, Enschede. 
http://www.itc.nl/library/papers_2013/phd/ullah.pdf

[14] Tempfli, K. (Editor), Huurneman, G. (Editor), Bakker, W. (Editor), Janssen, L. (Editor), Bakker, W., Feringa, W., Gieske, A., Grabmaier, K., Hecker, C., Horn, J., et al. (2009) Principles of Remote Sensing: An Introductory Textbook. 4th Edition, ITC, Enschede.

[15] Chappelle, E., Kim, M. and McMurtrey, J. (1992) Ratio Analysis of Reflectance Spectra (RARS): An Algorithm for the Remote Estimation of the Concentrations of Chlorophyll A, Chlorophyll B, and Carotenoids in Soybean Leaves. Remote Sensing of Environment, 39, 239-247. http://dx.doi.org/10.1016/0034-4257(92)90089-3

[16] Pinter, P., Hatfield, J., Schepers, J., Barnes, E., Moran, M.S., Daughtry, C., et al. (2003) Remote Sensing for Crop Management. Photogrammetric Engineering and Remote Sensing, 69, 647-664. http://dx.doi.org/10.14358/PERS.69.6.647

[17] Slaton, M., Hunt, E. and Smith, W. (2001) Estimating near Infrared Leaf Reflectance from Leaf Structural Characteristics. American Journal of Botany, 88, 278-284. http://dx.doi.org/10.2307/2657019

[18] Asner, G.P. (1998) Biophysical and Biochemical Sources of Variability in Canopy Reflectance. Remote Sensing of Environment, 64, 234-253. http://dx.doi.org/10.1016/S0034-4257(98)00014-5

[19] Curran, P., Dungan, J. and Peterson, D. (2001) Estimating the Foliar Biochemical Concentration of Leaves with Reflectance Spectrometry Testing the Kokaly and Clark Methodologies. Remote Sensing of Environment, 76, 349-359. http://dx.doi.org/10.1016/S0034-4257(01)00182-1

[20] Clevers, J., De Jong, S., Epema, G., Van der Meer, F., Bakker, W., Skidmore, A., et al. (2002) Derivation of the Red Edge Index Using the MERIS Standard Band Setting. International Journal of Remote Sensing, 23, 3169-3184. http://dx.doi.org/10.1080/01431160110104647

[21] Asner, G.P. and Vitousek, P.M. (2005) Remote Analysis of Biological Invasion and Biogeochemical Change. Proceedings of the National Academy of Sciences of the United States of America, 102, 4383-4386.

[22] Darvishzadeh, R., Skidmore, A., Schlerf, M. and Atzberger, C. (2008) Inversion of a Radiative Transfer Model for Estimating Vegetation LAI and Chlorophyll in a Heterogeneous Grassland. Remote Sensing of Environment, 112, 25922604. http://dx.doi.org/10.1016/j.rse.2007.12.003

[23] Schlerf, M., Atzberger, C., Hill, J., Buddenbaum, H., Werner, W. and Schuler, G. (2010) Retrieval of Chlorophyll and Nitrogen in Norway Spruce (Picea abies L. Karst.) Using imaging spectroscopy. International Journal of Applied Earth Observation and Geoinformation, 12, 17-26. http://dx.doi.org/10.1016/j.jag.2009.08.006

[24] Ribeiro da Luz, B. (2006) Attenuated Total Reflectance Spectroscopy of Plant Leaves: A Tool for Ecological and Botanical Studies. New Phytologist, 172, 305-318. http://dx.doi.org/10.1111/j.1469-8137.2006.01823.x

[25] Fabre, S., Lesaignoux, A., Olioso, A. and Briottet, X. (2011) Influence of Water Content on Spectral Reflectance of Leaves in the 3 - $15 \mu \mathrm{m}$ Domain. IEEE Geoscience and Remote Sensing Letters, 8, 143-147. http://dx.doi.org/10.1109/LGRS.2010.2053518

[26] Gerber, F., Marion, R., Olioso, A., Jacquemoud, S., da Luz, B. and Fabre, S. (2011) Modeling Directional-Hemispherical Reflectance and Transmittance of Fresh and Dry Leaves from $0.4 \mu \mathrm{m}$ to $5.7 \mu \mathrm{m}$ with the PROSPECT-VISIR Model. Remote Sensing of Environment, 115, 404-414. http://dx.doi.org/10.1016/j.rse.2010.09.011

[27] Coblentz, W.W. (1913) The Diffuse Reflecting Power of Various Substances. Bulletin of the Bureau of Standards, 9, 283-325. http://dx.doi.org/10.6028/bulletin.214

[28] Gates, D.M. and Tantraporn, W. (1952) The Reflectivity of Deciduous Trees and Herbaceous Plants in the Infrared to 25 Microns. Science, 115, 613-616. http://dx.doi.org/10.1126/science.115.2997.613

[29] Wong, C.L. and Blevin, W.R. (1967) Infrared Reflectance’s of Plant Leaves. Australian Journal of Biological Science, 20, 501-508.

[30] Kranner, I., Kastbergerb, G., Hartbauerb, M. and Pritcharda, H.W. (2010) Noninvasive Diagnosis of Seed Viability Using Infrared Thermography. Proceedings of the National Academy of Sciences of the United States of America, 107, 3912-3917.

[31] Eitel, J.U., Keefe, R.F., Long, D., Davis, A. and VierlingL, A. (2010) Active Ground Optical Remote Sensing for Improved Monitoring of Seedling Stress in Nurseries. Sensors, 10, 2843-2850. http://dx.doi.org/10.3390/s100402843

[32] Lee, S.H. and Kim, Y.H. (2004) Thermal and Visual Image Characteristics of Potato Transplants as Affected by Photosynthetic Photon Flux and Electrical Conductivity. 2004 ASAE Annual Meeting, American Society of Agricultural and Biological Engineers, 044101.

[33] Weatherspoon P. and Laacke R.J. (1984) Infrared Thermography for Assessing Seedling -Condition Rationale and Preliminary Observations. California. Proceedings of the Workshop on Evaluating Seedling Quality: Principles, Procedures, and Predictive Abilities of Major Tests, United States Department of Agriculture, Forest Service, California, 127-135. 
[34] Zhang, X., Liu, F., He, Y. and Li, X. (2012) Application of Hyperspectral Imaging and Chemometric Calibrations for Variety Discrimination of Maize Seeds. Sensors, 12, 17234-17246. http://dx.doi.org/10.3390/s121217234

[35] Ljungberg, S. and Jonsson, O. (2002) Infrared Thermography: A Tool to Map Temperature Anomalies of Plants in a Greenhouse Heated by Gas Fired Infrared Heaters. Proceedings of Thermosense XXIV, 4710, 399-406.

[36] Martin, E. (2009) Methods of Determining When to Irrigate. Cooperative Extension. College of Agriculture and Life Sciences, The University of Arizona, Tucson. http://extension.arizona.edu/sites/extension.arizona.edu/files/pubs/az1220.pdf

[37] Jones, H., Serraj, R., Loveys, B., Xiong, L., Wheaton, A. and Price, A. (2009) Thermal Infrared Imaging of Crop Canopies for the Remote Diagnosis and Quantification of Plant Responses to Water Stress in the Field. Functional Plant Biology, 36, 978-989. http://dx.doi.org/10.1071/FP09123

[38] Idso, S. (1982) Non-Water-Stressed Baselines: A Key to Measuring and Interpreting Plant Water Stress. Agriculture Meteorology, 27, 59-70.

[39] Idso, S., Pinter, J. and Reginato, R. (1990) Non-Water-Stressed Baselines: The Importance of Site Selection for Air Temperature and Air Vapor Pressure Deficit Measurements. Agricultural and Forest Meteorology, 53, 73-80. http://dx.doi.org/10.1016/0168-1923(90)90125-P

[40] Alves, I. and Pereira, L. (2000) Non-Water-Stressed Baselines for Irrigation Scheduling with Infrared Thermometers: A New Approach. Irrigation Science, 19, 101-106. http://dx.doi.org/10.1007/s002710050007

[41] Alderfasi, A. and Nielsen, D. (2001) Use of Crop Water Stress Index for Monitoring Water Status and Scheduling Irrigation in Wheat. Agricultural Water Management, 47, 69-75. http://dx.doi.org/10.1016/S0378-3774(00)00096-2

[42] Wanjura, D. and Upchurch, D.R. (2002) Water Status Response of Corn and Cotton to Altered Irrigation. Irrigation Science, 21, 45-55. http://dx.doi.org/10.1007/s00271-001-0049-4

[43] Gontia, N. and Tiwari, K. (2008) Development of Crop Water Stress Index of Wheat Crop for Scheduling Irrigation Using Infrared Thermometry. Agriculture Water Management, 95, 1144-1152. http://dx.doi.org/10.1016/j.agwat.2008.04.017

[44] Leinonen, I. and Jones, H.G. (2004) Combining Thermal and Visible Imagery for Estimating Canopy Temperature and Identifying Plant Stress. Journal of Experimental Botany Volume, 55, 1423-1431. http://dx.doi.org/10.1093/jxb/erh146

[45] O’Shaughnessy, S. and Evett, S. (2010) Canopy Temperature Based System Effectively Schedules and Controls Center Pivot Irrigation of Cotton. Agricultural Water Management, 97, 1310-1316. http://dx.doi.org/10.1016/j.agwat.2010.03.012

[46] Bockhold, D.L., Thompson, A.L., Sudduth, K.A. and Henggeler, J.C. (2011) Irrigation Scheduling Based on Crop Canopy Temperature for Humid Environments. American Society of Agricultural and Biological Engineers, 54, 20212028.

[47] O’Shaughnessy, S.A., Evett, S., Colaizzi, P. and Howell, T.A. (2012) A Crop Water Stress Index and Time Threshold for Automatic Irrigation Scheduling of Grain Sorghum. Agricultural Water Management, 107, 1310-1316. http://dx.doi.org/10.1016/j.agwat.2012.01.018

[48] Ballester, C., Castel, J., Jiménez-Bello, M., Castel, J. and Intrigliolo, D. (2013) Thermographic Measurement of Canopy Temperature Is a Useful Tool for Predicting Water Deficit Effects on Fruit Weight in Citrus Trees. Agricultural Water Management, 122, 1-6. http://dx.doi.org/10.1016/j.agwat.2013.02.005

[49] Bajons, P., Klinger, G. and Schlosser, V. (2005) Determination of Stomatal Conductance by Means of Infrared Thermography. Infrared Physics and Technology, 46, 429-439. http://dx.doi.org/10.1016/j.infrared.2004.09.001

[50] Blonquist, J.J., Normanb, J. and Bugbeec, B. (2009) Automated Measurement of Canopy Stomatal Conductance Based on Infrared Temperature. Agricultural and Forest Meteorology, 149, 1931-1945. http://dx.doi.org/10.1016/j.agrformet.2009.06.021

[51] Granta, O., Daviesa, M.J., Jamesa, M.C., Johnsona, A.W., Leinonenb, I. and Simpsona, D.W. (2012) Thermal Imaging and Carbon Isotope Composition Indicate Variation amongst Strawberry (Fragaria $\times$ ananassa) Cultivars in Stomatal Conductance and Water Use Efficiency. Environmental and Experimental Botany, 76, 7-15. http://dx.doi.org/10.1016/j.envexpbot.2011.09.013

[52] Jones, H.G. (2004) Irrigation Scheduling: Advantages and Pitfalls of Plant-Based Methods. Journal of Experimental Botany, 55, 2427-2436. http://dx.doi.org/10.1093/jxb/erh213

[53] Padhi, J., Misra, R. and Payero, J. (2012) Estimation of Soil Water Deficit in an Irrigated Cotton Field with Infrared Thermography. Field Crops Research, 44, 231-237.

[54] Wanga, X., Yang, W., Wheaton, A., Cooley, N. and Moran, B. (2010) Automated Canopy Temperature Estimation via Infrared Thermography: A First Step towards Automated Plant Water Stress Monitoring. Computers and Electronics in Agriculture, 73, 74-83. http://dx.doi.org/10.1016/j.compag.2010.04.007 
[55] Asher, B.J., Bar Yosef, B. and Volinsky, R. (2012) Ground-Based Remote Sensing System for Irrigation Scheduling. Biosystems Engineering, 114, 444-453. http://dx.doi.org/10.1016/j.biosystemseng.2012.09.002

[56] Panigadaa, C., Rossinia, M., Meronia, M., Ciliaa, C., Busettoa, L., Amaduccid, S., et al. (2014) Fluorescence, PRI and Canopy Temperature for Water Stress Detection in Cereal Crops. International Journal of Applied Earth Observation and Geoinformation, 30, 167-178. http://dx.doi.org/10.1016/j.jag.2014.02.002

[57] Abbas, A., Khanb, S., Hussainc, N., Hanjra, M. and Saud, A. (2013) Characterizing Soil Salinity in Irrigated Agriculture Using a Remote Sensing Approach. Physics and Chemistry of the Earth, Parts A/B/C, 55-57, 43-52. http://dx.doi.org/10.1016/j.pce.2010.12.004

[58] Ben-Dor, E., Metternicht, G., Goldshleger, N., Mor, E., Mirlas, V. and Basson, U. (2008) Review of Remote SensingBased Methods to Assess Soil Salinity. In: Metternichtand, G. and Zinck, A., Eds., Remote Sensing of Soil Salinization Impact on Land Management, CRC Press, Boca Raton, 377.

[59] Urrestarazu, M. (2013) Infrared Thermography Used to Diagnose the Effects of Salinity in a Soilless Culture. Quantitative InfraRed Thermography Journal, 10, 1-8. http://dx.doi.org/10.1080/17686733.2013.763471

[60] Xu, H., Zhu, S., Ying, Y. and Jiang, H. (2006) Early Detection of Plant Disease Using Infrared Thermal Imaging. Proceedings of Optics for Natural Resources, Agriculture, and Foods, 6381, 638110.

[61] Olivier, M., Heming, S. and Adams, G.G. (2003) Exploring the Spatial Variation of Take-All (Gaeumannemyces graminis var. tritici) for Site-Specific Management. In: 4th European Conference on Precision Agriculture, Wageningen Academic Publishers, Berlin, 481-486.

[62] Moshou, D., Bravo, C., West, J., Wahlcn, S., McCann, A. and Ramon, H. (2004) Automatic Detection of Yellow Rust in Wheat Using Reflectance Measurements and Neural Networks. Computers and Electronics in Agriculture, 44, 173188. http://dx.doi.org/10.1016/j.compag.2004.04.003

[63] Oerke, E.-C., Steiner, U., Dehne, H.-W. and Lindenthal, M. (2006) Thermal Imaging of Cucumber Leaves Affected by Downy Mildew and Environmental Conditions. Experimental Botany, 57, 2121-2132. http://dx.doi.org/10.1093/jxb/erj170

[64] Lindenthal, M., Steiner, U., Dehne, H.-W. and Oerke, E.-C. (2005) Effect of Downy Mildew Development on Transpiration of Cucumber Leaves Visualized by Digital Infrared Thermography. Phytopathology, 95, 233-240. http://dx.doi.org/10.1094/PHYTO-95-0233

[65] Oerke, E.-C., Lindenthal, M., Fröhling, P. and Steiner, U. (2005) Digital Infrared Thermography for the Assessment of Leaf Pathogens. The 5th European Conference on Precision Agriculture, Uppsala, 9-12 June 2005, 91-98.

[66] Oerke, E.-C., Fröhling, P. and Steiner, U. (2011) Thermographic Assessment of Scab Disease on Apple Leaves. Precision Agriculture, 12, 699-715. http://dx.doi.org/10.1007/s11119-010-9212-3

[67] Stoll, M., Schultz, H.R. and Loehnertz, B.B. (2008) Exploring the Sensitivity of Thermal Imaging for Plasmopara viticola Pathogen Detection in Grapevines under Different Water Status. Functional Plant Biology, 35, 281-288. http://dx.doi.org/10.1071/FP07204

[68] Smith, R., Barrs, H., Steiner, J. and Stapper, M. (1985) Relationship between Wheat Yield and Foliage Temperature: Theory and Its Application to Infrared Measurements. Agricultural and Forest Meteorology, 36, 129-143. http://dx.doi.org/10.1016/0168-1923(85)90005-X

[69] Stajnko, D., Lakota, M. and Hocevar, M. (2004) Estimation of Number and Diameter of Apple Fruits in an Orchard during the Growing Season by Thermal Imaging. Computer and Electronics in Agriculture, 42, 31-42. http://dx.doi.org/10.1016/S0168-1699(03)00086-3

[70] Bulanon, D.M., Burks, T.F. and Alchanatis, V. (2008) Study on Temporal Variation in Citrus Canopy Using Thermal Imaging for Citrus Fruit Detection. Biosystems Engineering, 101, 161-171. http://dx.doi.org/10.1016/j.biosystemseng.2008.08.002

[71] Du, W., Zhang, L., Hu, Z., Shamaila, Z., Zeng, A., Song, J., et al. (2011) Utilization of Thermal Infrared Image for Inversion of Winter Wheat Yield and Biomass. Spectroscopy and Spectral Analysis, 33, 1587-1592.

[72] Hu, Z.-F., Zhang, L.-D., Wang, Y.-X., Shamaila, Z., Zeng, A.-J., Song, J.-L., Liu, Y.-J., Wolfram, S., Joachim, M., He, X.-K. (2013) Application of BP Neural Network in Predicting Winter Wheat Yield Based on Thermography Technology. Spectroscopy and Spectral Analysis, 33, 1587-1592.

[73] Wang, Q., Nuske, S., Bergerman, M. and Singh, S. (2012) Automated Crop Yield Estimation for Apple Orchards. In: Desai, J.P., Dudek, G., Khatib, O. and Kumar, V., Eds., Experimental Robotics: The 13th International Symposium on Experimental Robotics, Springer, 745-758.

[74] Jensen, T., Apan, A. and Zeiler, L. (2009) Crop Maturity Mapping Using a Low Cost Low Altitude Remote Sensing System. Proceedings of Surveying and Spatial Sciences Institute Biennial International Conference, Adelaide, 28 September-2 October 2009, 1231-1242. 
[75] Scotford, I. and Miller, P. (2004) Combination of Spectral Reflectance and Ultrasonic Sensing to Monitor the Growth of Winter Wheat. Biosystems Engineering, 87, 27-38. http://dx.doi.org/10.1016/j.biosystemseng.2003.09.009

[76] Linke, M., Geyer, M., Beuche, H. and Hellebrand, H.J. (2000) Possibilities and Limits of the Use of Thermography for the Examination of Horticultural Products. Agrartechnische Forschung, 6, 110-114.

[77] Danno, A., Miyazato, M. and Ishiguro, E. (1980) Quality Evaluation of Agricultural Products by Infrared Imaging Method: Maturity Evaluation of Fruits and Vegetables. Memoirs of the Faculty of Agriculture, Kagoshima University, Kagoshima, 157-164.

[78] Hellebrand, H.J., Linke, M., Beuche, H., Herold, B. and Geyer, M. (2000) Horticultural Products Evaluated by Thermography. Institute of Agricultural Engineering Bornim, Potsdam, Germany.

http://www2.atb-potsdam.de/Hauptseite-deutsch/Institut/Abteilungen/abt2/Mitarbeiter/jhellebrand/jhellebrand/Publikat /AgEng2000PH3.pdf

[79] Mohsenin, N. (1986) Physical Properties of Plant and Animal Materials. 2nd Edition, Routledge, London.

[80] Pen, C., Bilanski, W. and Fuzzen, D. (1985) Classification Analysis of Good and Bruised Peeled Apple Tissue Using Optical Reflectance. Transactions of the ASABE, 28, 326-330. http://dx.doi.org/10.13031/2013.32251

[81] Upchurch, B., Affeldt, H., Hruschka, W., Norris, K. and Troop, J. (1990) Spectrophotometric Study of Bruises on Whole, “Red Delicious” Apples. American Society of Agricultural and Biological Engineers, 33, 585-589. http://dx.doi.org/10.13031/2013.31370

[82] Upchurch, B., Throop, J. and Aneshansley, D. (1994) Influence of Time, Bruise-Type, and Severity on Near-Infrared Reflectance from Apple Surfaces for Automatic Bruise Detection. American Society of Agricultural and Biological Engineers, 37, 1571-1575. http://dx.doi.org/10.13031/2013.28243

[83] Wen, Z. and Tao, Y. (2000) Dual-Camera NIR/MIR Imaging for Stem-End/Calyx Identification in Apple Defect Sorting. Transaction of the ASABE, 43, 449-452. http://dx.doi.org/10.13031/2013.2724

[84] Gowen, A., O’Donnell, C., Cullen, P., Downey, G. and Frias, J. (2007) Hyperspectralmaging-An Emerging Process Analytical Tool for Food Quality and safety Control. Trends in Food Science \& Technology, 18, 590-598. http://dx.doi.org/10.1016/j.tifs.2007.06.001

[85] Ueno, A., Shu, Z. and Takahashi, T. (2008) Determination of Spectral Wavelengths for Detecting Bruise Defects on Apple Fruits. Journal of the Japanese Society of Agricultural Machinery, 70, 63-68.

[86] Zhao, J., Liu, J., Chen, Q. and Vittayapadung, S. (2008) Detecting Subtle Bruises on Fruits with Hyperspectral Imaging. Transactions of Chinese Society for Agricultural Engineering, 39, 106-109.

[87] Varith, J., Hyde, G., Baritelle, A., Fellman, J. and Sattabongkot, T. (2003) Non-Contact Bruise Detection in Apples by Thermal Imaging. Innovative Food Science and Emerging Technologies, 4, 211-218. http://dx.doi.org/10.1016/S1466-8564(03)00021-3

[88] Danno, A., Miyazato, M. and Ishiguro, E. (1978) Quality Evaluation of Agricultural Products by Infrared Imaging Method: Grading of Fruits for Bruise and Other Surface Defects. Memoirs of the Faculty of Agriculture, Kagoshima University, 14, 123-138.

[89] Vanlinden, V., Vereycken, R., Bravo, C., Ramon, H. and De Baerdemaeker, J. (2003) Detection technique for tomato bruise damage by thermal imaging. Acta Horticulturae, 599, 389-394.

[90] Baranowski, P., Mazurek, W., Wozniak, J. and Majewska, U. (2009) Detection of Early Bruises in Apples Using Hyperspectral Data and Thermal Imaging. Food Engineering, 110, 345-355.

http://dx.doi.org/10.1016/j.jfoodeng.2011.12.038

[91] Wu, A., Salerno, A., Schonbach, B., Hallin, H. and Busse, G. (1997) Phase-Sensitive Modulation Thermography and Its Applications for NDE. An International Conference on Thermal Sensing and Imaging Diagnostic Applications, 3056, 176-182. http://dx.doi.org/10.1117/12.271641

[92] Kim, G., Kim, G.-H., Park, J., Kim, D.-Y. and Cho, B.-K. (2014) Application of Infrared Lock-In Thermography for the Quantitative Evaluation of Bruises on Pears. Infrared Physics \& Technology, 63, 133-139. http://dx.doi.org/10.1016/j.infrared.2013.12.015 
Scientific Research Publishing (SCIRP) is one of the largest Open Access journal publishers. It is currently publishing more than 200 open access, online, peer-reviewed journals covering a wide range of academic disciplines. SCIRP serves the worldwide academic communities and contributes to the progress and application of science with its publication.

Other selected journals from SCIRP are listed as below. Submit your manuscript to us via either submit@scirp.org or Online Submission Portal.
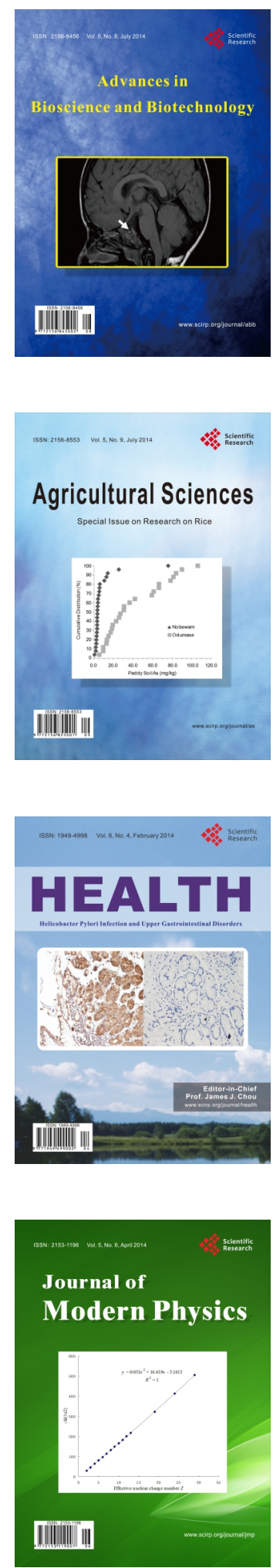
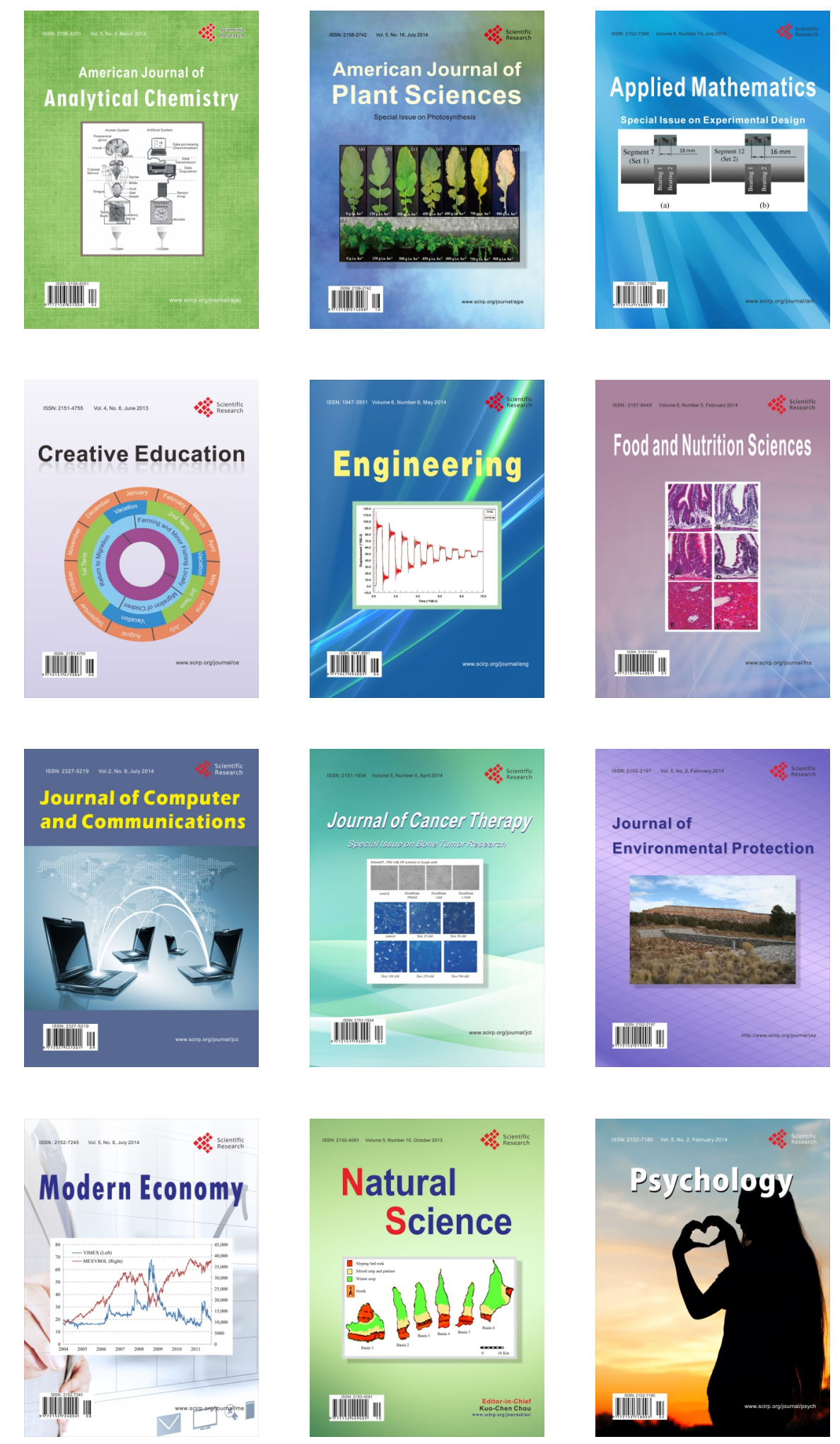